te treści, których „odkodowanie” pozwala dopiero umieścić tekst w odpowiednim kontekście socjokulurowym. Efekty tych analiz bywają różne, dla badaczy przywiązanych do tradycyjnego warsztatu historycznego (wbrew różnym opiniom niezmiennie, moim zdaniem, zachowującego aktualność) niekiedy będą to nieco ekstrawaganckie zabawy leksykalne, jak chociażby rozważania o terminologii dotyczącej odczuć smaku w satyrach (rozdz. 2-4 w części II). Nie zmienia to jednak faktu, że przyjęty przez autorkę schemat (s. 22-23): uwzględniający relacje przy stole między bogami i ludźmi, relacje ludzi ze środowiskiem naturalnym, kryteria wyboru produktów żywnościowych, przygotowanie posiłków (czyli „od kuchni do gastronomii") oraz konsumpcja, znajduje odzwierciedlenie w literaturze zarówno na poziomie realiów, jak i symboliki.

Danuta Musiat (Toruń)

\title{
Krzysztof Nawotka, Alexander the Great, Cambridge Scholars Publishing, Newcastle upon Tyne 2010, ss. 440
}

S

wego czasu Ernst Badian zaapelował do badaczy Aleksandra Wielkiego o „moratorium na obszerne syntezy oraz szerokie interpretacje”. Zalecał wówczas pracę u podstaw, stwierdzając, że jest jeszcze wiele do zrobienia, choć, jak zaznaczał „oczywiście łatwiej i zarazem przyjemniej jest napisać jeszcze jedną książkę, ukazującą indywidualną wizję autora, aniżeli zająć się szczegółowymi zagadnieniami"1. Sam Badian niestety usłuchał tego wezwania. Wielu innych uczonych na szczęście nie. W rezultacie powstało wiele nowych książek na temat Aleksandra². Są wśród nich różne prace, poświęcone rozmaitym zagadnieniom szczegółowym, a także różnej wartości syntezy.

Wśród tych ostatnich obserwujemy różne tendencje skutkujące zarówno idealizacją, jak i racjonalizacją postaci i działalności Aleksandra Wielkiego. Jak bowiem

${ }^{1}$ E. Badian, Some Recent Interpretations of Alexander, [in:] Alexandre le Grand, Fondation Hardt 22, 1975, s. 300.

${ }^{2}$ Zob. m.in. J. Carsen, Alexander the Great (1970-1990) [in:] Alexander the Great. Reality and Myth, red. J. Carlsen i in., Roma 1993, s. 41. 
ongiś celnie zauważył Welles: „Jest wielu Aleksandrów i prawdopodobnie nigdy nie będzie ostatecznego jego obrazu (definitive Alexander)"3.

W historiografii Aleksandra przez długi czas dominowała tendencja idealizacyjna. Badacze zafascynowani postacią tworzyli jej obraz często w sposób subiektywny, szukając w źródłach potwierdzenia własnych z góry powziętych sądów. Mieszano przy tym niejednokrotnie zamiary Aleksandra ze skutkami jego działalności, usiłując przypisać mu koncepcje, o których źródła milczą. Powstawały w ten sposób prace często bardzo sugestywne, niekiedy nawet bardzo wybitne (e.g. J. G. Droysen, U. Wilcken, W. W. Tarn, P. Cloche, F. Schachermeyr, L. Homo, N. G. L. Hammond).

Ostatnie dziesięciolecia przyniosły reakcję na te często bardziej poetyckie niż historyczne wizje (e.g. R.D. Milns, P. Green, P. Briant, P. Goukowsky, I. Szifman, J. R. Hamilton, P. Briant, A. B. Bosworth). Triumf odniósł w badaniach nurt określany tu mianem racjonalizacji. Mam jednak wątpliwości, czy „racjonalizując” działalność Aleksandra, do końca odkrywamy jego wielkość. Owe wątpliwości, wprawdzie nieśmiało, zaczynają się wszakże pojawiać w nauce i wydaje się, że przyszłe badania muszą również uwzględniać krytykę „racjonalizmu”. Frank Holt słusznie przestrzega przed nową ortodoksją ukazującą paranoję, megalomanię, alkoholizm i brutalność Aleksandra ${ }^{4}$.

Z pewnością potrzebujemy obecnie pracy mądrej mądrością powikłanej dyskusji, nieobciążonej idealizacją ani grzechem „deheroizacji” Aleksandra Wielkiego. Prawda nie leży pośrodku, ale też nie znajduje się na żadnym z marginesów, ani tym wytyczonym przez Tarna, ani tym ustalonym przez Badiana i jego następców5 5

Praca Nawotki ${ }^{6}$ jest, jak sądzę, krokiem w tym właśnie kierunku. Jest to pierwsza duża biografia Aleksandra od czasu opublikowania cennej monografii Boswortha ${ }^{7}$. Uwzględnia ona postęp badań, nowe prace na temat Wschodu i Macedonii, wprowadza w większej mierze mniej wcześniej wykorzystywane źródła.

Jak sam Autor deklaruje, nie ma ambicji wypowiadania się na temat aspektu wojskowego działalności Aleksandra. Interesuje go Aleksander jako człowiek i jako

${ }^{3}$ C. B. Welles, recenzja z Schachermeyra, Alexander der Grosse. Ingenium und Macht, AJA 55, 1951, ss. 433-436 (=) The Impact of the Alexander the Great, (ed.) E. Borza, The Pennsylvania State University 1974, s. 9.

${ }^{4}$ I. Worthington, How "Great" was Alexander?, AHB 13, 2, 1999; Frank L. Holt, Alexander the Great Today: In the Interests of Historical Accuracy?, AHB 13, 3, 1999, ss. 111-117; I. Worthington, Alexander the Great and the "Interests of Historical Accuracy": A Reply, AHB 13, 4, 1999, ss. 136-140.

5 R. Kulesza, Aleksander Wielki (przegląd badań), „Przegląd Humanistyczny”, s.144-150.

${ }^{6}$ Wcześniejsza jej wersja ukazała się w języku polskim w serii monografii Fundacji na Rzecz Nauki Polskiej (K. Nawotka, Aleksander Wielki, Wrocław 2004).

7 A. B. Bosworth, Conquest and Empire: The Reign of Alexander the Great, Cambridge 1988. 
polityk o niezwykłych zdolnościach i niebywałej charyzmie, ale zarazem człowiek, który popełniał błędy i okazywał niekiedy najgorsze cechy charakteru (s. VIII). Zauważmy jednak, że jakkolwiek nie jest historykiem wojskowości, Nawotka rzetelnie przedstawia również kwestie związane z armią i głównymi bitwami Aleksandra.

W książce ukazano całe życie Aleksandra, poczynając od lat najmłodszych. Nawotka daje generalny przegląd dziejów Macedonii i dziejów Filipa II. Zdaniem Nawotki „w czasach Aleksandra Macedończycy tworzyli osobny ethnos. Co więcej byli świadomi i dumni z tego powodu” (s. 5-6). Zarazem wedle Nawotki: „najprawdopodobniej mieli oni te same protogreckie korzenie, co członkowie historycznych plemion greckich” (s. 7).

„Każdy badacz zajmujący się Aleksandrem tworzy swojego własnego Aleksandra" (Every Alexander Historian creates his or her own Alexander)" nie forsuje jednak swojej wizji Macedończyka. Zgodnie z deklarowanym zamiarem „zsyntetyzowania całej najnowszej literatury przedmiotu (to synthesise all modern literatur)" (s. XII) rzetelnie referuje dyskusję naukową, zapewniając czytelnikowi orientację w głównych, podnoszonych w niej zagadnieniach.

Autor przedstawia bardzo wyważony obraz panowania Aleksandra, stroniąc od wyrażania radykalnych opinii. Siłą rzeczy różnym zagadnieniom przygląda się z różną uwagą. Według Nawotki Filip II zbudował swoją armię ex nibilo (s. 24), w co osobiście wątpię, choć wpisuje się to w jego obraz jako „ojca założyciela”. Może nie do końca ukazano Filipa II jako autora „rewolucji cywilizacyjnej”. Być może zbyt mało uwagi poświęca Autor wizycie w oazie Siwa, sprawie proskynesis, sprawie Klejtosa i spisku paziów, ale wszystkie relacjonuje w sposób rzetelny.

Książka Nawotki jest, jak sądzę, ważnym wkładem w dyskurs naukowy o Aleksandrze Wielkim. Warto przy tym podkreślić, że w znacznej części opiera się na własnych badaniach szczegółowych Autora? .

Ryszard Kulesza (Warszawa)

${ }^{8}$ U. Wilcken, Alexander der Grosse, Leipzig 1931, p. VII = Alexander the Great, with preface, notes and bibliography by E.N. Borza, New York 1967, s. 29.

9 Poza cytowanymi w książce warto zwrócić uwagę na najnowszą komentowaną edycję PseudoKallistenesa przygotowaną przez Nawotkę (Pseudo-Callisthenes Historia Alexandri Magni/Pseudo-Kallistenes, Romans o Aleksandrze, przekład, wstęp i komentarz Krzysztof Nawotka, Fontes Historiae Antiquae. Zeszyty Źródłowe Zakładu Historii Społeczeństw Antycznych, red. L. Mrozewicz, M. Musielak, z. XIV, Wydawnictwo Naukowe Uniwersytetu im. Adama Mickiewicza w Poznaniu, Poznań 2010, ss. 337, il. 14). 


\section{Przemysław Gawron, Hetman koronny w systemie ustrojowym Rzeczypospolitej $w$ latach 1581-1646, Warszawa 2010, Wydaw- nictwo Neriton, ss. 507}

$\mathrm{W}$ 2010 r. została opublikowana praca Przemysława Gawrona dotycząca funkcjonowaniu urzędu hetmana wielkiego koronnego w systemie ustrojowym XVI i XVII-wiecznej Rzeczypospolitej. Autor książki jest pracownikiem Uniwersytetu Kardynała Stefana Wyszyńskiego w Warszawie. Zainteresowania badawcze autora koncentrują się przede wszystkim na tematyce wojskowości staropolskiej i powszechnej XVI i XVII wieku.

Autor wskazuje we wstępie, że do tej pory w historiografii polskiej nigdy nie powstało całościowe opisanie problematyki funkcjonowania urzędu hetmańskiego na tle specyficznego ustroju XVI i XVII- wiecznej Rzeczypospolitej. Ta okoliczność skłoniła autora do podjęcia badań nad tym interesującym z punktu widzenia historyka wojskowości zagadnieniem. Warto zaznaczyć, że w dotychczasowej historiografii ukazało się wiele prac, omawiających życie i działalność wojskową osób, które pełniły urząd hetmana koronnego. Niestety żadna z prac nie daje nam pełnego obrazu funkcjonowania tego urzędnika w realiach ustrojowych Rzeczypospolitej szlacheckiej. Za cezury autor przyjął 1581 i 1646 rok. Pierwsza data oznacza nadanie buławy hetmańskiej Janowi Zamoyskiemu, jednemu z najwybitniejszych postaci, które miały możliwość dzierżenia buławy hetmańskiej. Natomiast rok 1646 oznacza śmierć innego znanego wodza tamtej epoki - Stanisława Koniecpolskiego.

W swej pracy Gawron skupił się na kilku zasadniczych problemach: po pierwsze na relacjach pomiędzy urzędnikiem hetmańskim a królem, po drugie zaś na jego stosunkach z sejmem i sejmikami ziemskimi oraz innymi instytucjami wojskowoadministracyjnymi Rzeczypospolitej. Badacza interesują przy tym zagadnienia stricte polityczne i wojskowe, co stanowi niezwykle interesujący temat dla osób zajmujących się na co dzień historią Rzeczypospolitej w okresie nowożytnym.

Autor oparł pracę na szerokiej bazie źródłowej, w której znajdują się liczne pamiętniki, diariusze, a także korespondencja. Źródła obejmują nie tylko te wydane drukiem, ale również i te znajdujące się w różnych archiwach, także i tych zagranicznych. Warto zauważyć, że literatura przedmiotu jest również bardzo imponująca. Obejmuje ona szereg zagadnień wojskowych i politycznych omawianego okresu. Może to stanowić dowód, że omawiane przez autora zagadnienia były już w pewnym stopniu wcześniej opracowywane. 